\title{
Entrelacs
}

Cinéma et audiovisuel

Hors-série $n^{\circ} 4$ | 2016

Paysages en séries

\section{Paysage des morts}

\section{Maylis Asté et Marie Maillos}

\section{(2) OpenEdition}

Journals

Édition électronique

URL : http://journals.openedition.org/entrelacs/4425

DOI : 10.4000 /entrelacs.4425

ISBN : $2261-5482$

ISSN : 2261-5482

Éditeur

Éditions Téraèdre

Édition imprimée

Date de publication : 1 novembre 2016

ISSN : 1266-7188

\section{Référence électronique}

Maylis Asté et Marie Maillos, «Paysage des morts», Entrelacs [En ligne], Hors-série n 4 | 2016, mis en ligne le 07 février 2019, consulté le 24 septembre 2020. URL : http://journals.openedition.org/ entrelacs/4425; DOI : https://doi.org/10.4000/entrelacs.4425

Ce document a été généré automatiquement le 24 septembre 2020.

Tous droits réservés 


\title{
Paysage des morts
}

\author{
Maylis Asté et Marie Maillos
}

1 Le paysage familier, domestiqué, est fragile : il suffit d'une explosion, d'une bactérie, d'un barrage ou de l'envol d'un papillon pour qu'en un instant tout bascule. Ainsi, de l'inquiétante étrangeté aux lieux désaffectés, le paysage se transforme.

2 Si le cinéma post-apocalyptique fait depuis longtemps de la relation aux espaces un enjeu primordial, le genre sériel reprend cette trajectoire. Une espèce en péril lutte jour après jour pour sa survie. Cette humanité résiduelle parcourt un monde dérangé, où les codes spatio-temporels sont bouleversés.

3 Les paysages de l'apocalypse proposent un univers fracturé où toutes nos références sont malmenées. La mort elle-même ne constitue plus une frontière. Du désert américain aux montagnes savoyardes, Zombies et Revenants occupent le territoire. La mort, le cataclysme ou l'apocalypse ne sont que le prélude à l'avènement d'une posthumanité en confrontation permanente à son nouvel environnement. L'apocalypse, comme dans Le monde, la chair et le diable de Ranald MacDougall ${ }^{1}$, est un recommencement. La nouvelle figure anthropomorphe qui se dresse dans les paysages de l'apocalypse est en quête d'un refuge, d'une nouvelle terre promise.

4 Les univers dérangés et sans frontières de certaines séries déconstruisent nos espaces familiers. La "mise en paysage», ce regard qui embrasse, traduit alors un nouveau rapport aux espaces. Fascination, angoisse, monstruosité : paysages et personnages portent les marques de la fracture.

\section{NOTES}

1. The World, The Flesh and the Devil (1959) Le réalisateur substitute au carton "The End" celui de " The Beginning". 